cultivators. Colonel Ross, Inspector-General of Irrigation, has studied this subject most closely. Even in these deficient years there was water enough in the river if it could only be got on to the land. He has proved that, by a judicious system of canals, sluices, siphons, escapes, weirs, \&c., it may be arranged that, even in the worst years, the whole Nile valley shall receive its share of mud-charged water. This involves the construction of no great work like the Barrage (the most expensive does not exceed $£ 45,000)$, but of a great number of works costing from $f_{5} 5000$ to $f_{15}, 000$ each, requiring very careful designing, and built often in remote spots, where construction of any kind is difficult.

These works have been going on now for more than a year. When finished, as I hope they will be in 1893 , the whole outlay will be about $£ 600$,ooo. And then, I trust, the lands of Upper Egypt will yield their full crop, however defective may be the Nile flood.

14. Agricultural Roads.--Fifthly. A minor subject, and yet one of great value to the country, deserves notice here-namely, the introduction of agricultural roads, This reform is due to Riaz Pasha. Until two years ago. it would have been impossible to take a cart-load of agricultural produce from any one centre of population to another in the Delta. Comparatively few of the canals were adapted for boats, and the one means of transporting cotton to the railway stations or to the river was by camels, which, however well adapted for carrying burdens on the firm sand of the desert, are not suitable for the rich alluvial soil and the sloppy fields of the Nile valley. This is all being changed. The people have willingly accepted a tax never exceeding P.E. 4 or 5 per feddan for one year only, and, with the fund thus raised, a whole network of serviceable roads is being formed sufficiently adapted for this dry climate.

15. Corvée Abolition.-The above paragraphs describe generally the improvements that have been brought about in the last seven years. Second to none is the boon that has been conferred on Egypt in the abolition of the corvée. Previous to 1885 , the whole of the earth-work in the clearance and repairs of canals and embankments was effected by the forced, unpaid, unfed labour of the peasantry. In 1884 this labour amounted to 85,000 men working for 160 days. We were told that this was quite a necessary state of things, that it would be impossible to maintain the irrigation-works otherwise, and that the Egyptian peasant, unlike that of any other country, would not work for wages, and must be forced. We estimated that to redeem this corvée and to pay for all this labour would cost $£ 400,000$. Nubar Pasha, in the face of the greatest financial difficulty and opposition, managed to give an annual grant of $£ 250,000$ for this object. Riaz Pasha, at the end of 1889 , found means of granting the remaining $f, 150,000$, and in 1890 , for the first time perhaps in all history, there was no corvée in Egypt.

16. Canal Legislation.-When we began work here, we were much hampered by the want of any canal legislation, there being no law corresponding to what is found in India, Italy, and elsewhere, treating of the many conflicting questions connected with irrigation. After three years' discussion, a very useful Canal Act now exists, and the only misfortune is that it is not binding on residents of foreign nationality.

17. Storage of Nile Water.-Lastly, as regards our programme for the future, there is abundance to do in carrying out, year by year, solid unpretending reforms; but, besides these, a very large question is coming to the front. The restoration of the Barrage placed at our disposal all the water of low Nile, but the increase in the area irrigated outruns the increase in the water available, and we have to look for means of storing the surplus volume of the flood, and utilizing it when the river is low.

There are two ways in which this may probably be done. The first, which is connected with the name of an

$$
\text { NO. I I 29, VOL. 44] }
$$

ingenious American gentleman, Mr. Cope Whitehouse, is to divert a portion of the flood into a great natural depression existing west of the Nile valley, and there to form a storage reservoir, to be drawn upon as the water in the river decreases. This has been examined and found feasible, but the expense, probably $1 \frac{1}{2}$ millions sterling, is against it. The alternative project is to pond up water in the valley of the river itself above Assouan. This project is being studied at present. There can be hardly any further extension of the cotton cultivation if one or the other of these schemes is not executed. There is room enough in the country to employ both.

COLIN SCOTT MONCRIEFF, Under-Secretary of State, Public Works Department.

Cairo, March 5, r89r.

\section{THE SECOND ORNITHOLOGICAL CONGRESS.}

A FULL report of the proceedings of this important Congress can only be obtained when the official Comptis rendus are published, for the officers of one section were unable to attend the meetings of the other sections owing to the fact that all four sections sat at one and the same time. This is the only complaint we have to make concerning the recent proceedings, but as it affects the future of these useful reunions, we feel compelled to make our protest, because, by the simultaneous session of all the sections of a Congress, no man, however interested in the subjects under discussion, can hear all that he wishes to hear; the visitor has to choose between two meetings, both of which probably possess for him an equal interest. It must be obvious to everyone who had the privilege of attending the second Ornithological Congress that a great gathering of specialists such as that which took place last month must require more time than three days to discuss such varied problems as were placed before them at the recent meeting.

The city of Budapest was happily chosen as the meeting-place of the Congress, and it may well-be questioned whether there is any country in the world that could have offered so many attractions to the ornithologist as Hungary. The hospitality of the Hungarians is proverbial, the accommodation in the beautiful capital is unlimited, and access thereto is easy. After an enjoyable trip down the Danube from Vienna, the travellers found themselves at the opening conversazione of the Congress, which was celebrated in the Grand Hotel "Hungaria." Here the Hungarian Committee had assembled with all the members of the Congress to welcome the guests, and the inaugural banquet served as a pleasant medium for the introduction of the strangers. On May 17 the first general meeting of the Congress took place in the sumptuous theatre of the Hungarian National Museum. After some words of welcome from the Burgomaster of Budapest, the officers for the Congress were chosen as follows :- Honorary Presidents : Count Bethlen, Minister of Agriculture ; Count A. Csáky, Minister of Public Instruction; Mr. B. Kállay, Minister of Finance. Presidents: Prof. Victor Fatio (Geneva) and Mr. Otto Herman, M.P. Vice-Presidents : Dr. Rudolph Blasius (Brunswick), Prof. S. Brusina (Agram), Prof. R. Collett (Christiania), Mr. J. de Csató (Budapest), Dr. Otto Finsch (Bremen), Major Alex. von Homeyer (Greifswald), Dr. A. B. Meyer (Dresden), Dr. E. von Middendorf (Livonia), Dr. Emil Oustalet (Paris), Dr. Bowdler Sharpe (British Museum), Mr. E. von Szalay (Budapest), Victor Ritter Tschusi von Schmidhoffen (Hallein). General Secretary : Dr. G. von Horváth. Secretaries: Mr. E. Chernel von. Chernelháza, Dr. A. Lendl, Dr. L. Lorenz von Liburnau, Dr. A. Lovassy, Dr. I. von Madarász, Mr. O. Reiser, Prof. G. Szikla. Hon. Secretaries: Mr. E. de Gaál, Mr. B. de Lipthay, Mr. J. d'Ottlik. Quæstor: Mr. J. von 
Xántus. After preliminary reports, Major Alex. von Homeyer gave his reminiscences of travel in West Africa some years ago, and his imitations of the notes of African birds were strikingly rendered. Four different sections of the Congress were appointed, the names of the different delegates from foreign countries were read out, as well as letters of apology for their absence from several naturalists, Prof. Fürbringer, Baron de Selys Longchamps, and others.

The officers of the different sections were constituted as follows:- (I) Systematic Section : Presidents, Dr. Bowdler Sharpe (London) and Prof. Claus (Vienna); Vice-Presidents, Dr. A. Reichenow (Berlin) and Mr. C. G. Danford (Siebenburgen). (2) Biology and Oology : President, Dr. Rudolph Blasius. (3) Avigeographia: Presiclent, Dr. Palacky (Prag). (4) Economic Ornithology: P'resident, Major Alex, von Homeyer.

On the afternoon of May 17 many of the members of the Congress ascended the Blocksberg, to enjoy a view of the city of Budapest and the Danube flowing belowa view not to be surpassed in beauty and interest in any country.

On Monday, May 18 , the Systematic Section met in the lecture-theatre of the Polytechnicum, which was placed at the disposal of the Congress by Prof. Szabo, whose work is well known and appreciated in Great Britain. Papers were read by Prof. Klug, on some points in the anatomy of the stomach in birds, and by Dr. Bowdler Sharpe on the classification of birds, the latter lecture being illustrated by several large diagrams and a wax model of the phylogenetic tree, in which Prof. Fürbringer traces the evolution of birds from a reptilian stock. The remainder of the work of the Systematic Section consisted in the passing of the rules of nomenclature, as put forward by a committee consisting of Prof. Möbius, Dr. A. Reichenow, Count von Berlepoch, Dr. A. B. Meyer, and Dr. W. Blasius. The recommendations of this committee were adopted almost in their entirety by the meeting, after a two-days' discussion, notwithstanding some protests of Dr. Sharpe, and Mr. Büttikofer of the Royal Museum of Leyden, who found themselves in a hopeless minority. The chief points carried were: the adoption of the Ioth instead of the I2th edition of the "Systema Naturæ" of Linnæus, the recognition of trinomial names in certain cases, and the adoption of names, even faulty in construction or misspelt, with all the consequences. The tone of the report, however, is so moderate, and exhibits so much consideration for the methods of other ornithologists, that it ought to be possible now to arrive at a definite conclusion for European usage at least; and then it would be easy to assimilate the American and European methods of nomenclature.

In the afternoon of the $18 \mathrm{th}$, the Congress met in the Museum, and Dr. Otto Herman. M.P., gave an account of the distribution of birds in Hungary, and explained the collections which had been made specially for the Congress. These consisted of beautifully mounted cases of Hungarian birds with nests and natural surroundings: some very rare sfecies were included in the collection, which was the work of four ornithologists-Dr. O. Herman, M.P., Dr. Julius von Madarász, Mr. Chernel, and Prof. Szikla. These gentlemen had each occupied a station in different parts of Hungary, and had not only collected the series of birds exhibited, but had also made exact observations on migration and distribution. The Hungarian National Museum is a very fine building, and contains a collection which fairly surprised most of the visitors, the series of native birds being especially complete. Large groups of Laemmergeiers, Sea Eagles, Ospreys, \&c., with their nests, eggs, and young birds, are to be seen in the Bird-galleries, and these are principaily the work of a well-known Hungarian ornithologist, Dr. J. vcn Madarász. The collection of Mammalia also com- prises some great rarities, and the whole Museum teems with specimens procured by the veteran explorer, Mr. J. von Xántus, whose labours in Lower California and Central America, as well as in Borneo and the Sunda Islands, are also widely known. The Museum likewise contains a fine series of insects, especially Coleoptera, which were shown with much natural pride by Dr. Frivaldszky, who is responsible for the beautiful arrangement of the latter groups. The afternoon closed with an adjournment to the Hungarian Academy of Sciences, where Prof. Robert Collett read a paper on Arctic Bird-life before a crowded audience; and the evening concluded with a banquet at the "Archiduc Stephan" Hotel.

On Tuesday the debate on nomenclature was continued; and in the afternoon the Congress assembled on St. Margaret's Island, which forms a most delightful summer retreat for the inhabitants of Budapest, with its dozens of nightingales, its ruined cloisters, and its sulphur springs.

On Wednesday, the 2oth, the general meeting of the Congress was held to receive the reports of the different sections and committees, and the business was concluded. A farewell banquet took place in the evening, and the second Ornithological Congress came to an end.

Next day the members were scattered in different directions-some to their homes, some to join one of the pre-arranged excursions. These were three in numberone to the Hanság marshes and Fertö, a second to the Platten-See, and a third to the districts of the Drave. Of the first excursion, in which the writer took part, he can only say that, under the direction of Dr. von Madarász, the members of the Congress who accompanied it underwent a never-to-be-forgotten experience. The species of birds observed were mostly those unknown to an English naturalist, and the hospitality dispensed by Prince Esterhazy, Baron von Berg, and Count Széchenyi, is not likely to disappear from the memory of those who had the good fortune to partake of it.

\section{THE IMPERIAL PHYSICAL AND TECHNICAL} INSTITUTION AT BERLIN.

THE Imperial Physical and Technical Institution which was founded in 1887 at Charlottenburg, near Berlin, under the auspices of the German Government, has now been for some time in active operation, and recently there has been issued by the executive Director, Dr. L. Loewenherz, a Report on the work of the Institution up to the end of last year.

It may be remembered that the Institution has two main objects in view : first, that of physical and technical research appropriate to the practical development of manufacture-researches for instance as to the qualities of metals and materials and as to methods of construction and measurement; the second object being that of fundamental research in theoretical problems in physics, and the testing of all kinds of measuring apparatus applicable for use in science, art, and manufacture. It appears to undertake, therefore, investigations and verifications similar to those undertaken in this country by the Board of Trade, or at the Kew Observatoly; and, in France, by the Bureau International des Poids et Mesures. Its staff includes (exclusive of the clerical staff) a President, nominated by the Reichstag; a Director, with a Committee of seven members; seven scientific officers in the department of research ; four technical assistants, and several mechanics and machinists.

From time to time, as new methods of testing are adopted, or as fresh work is undertaken, explanatory papers are issued by the responsible officers of the Institution (printed by Julius Springer, Berlin); and the following papers have, amongst others, been already issued: - Karl Scheel, H. F. Wiebe, and Allr. Böttcher, on

NO. I I 29, VOL. 44] 